\title{
Symptoms, ventilatory function, and environmental exposures in Portland cement workers
}

\author{
H L ABRONS, ${ }^{1}$ M R PETERSEN, ${ }^{2}$ W T SANDERSON, ${ }^{2}$ A L ENGELBERG, ${ }^{3}$ \\ P HARBER ${ }^{4}$
}

From the West Virginia University School of Medicine,' and National Institute for Occupational Safety and Health, ${ }^{2}$ Division of Respiratory Disease Studies, Morgantown, WV 26505, American Medical Association, ${ }^{3}$ Chicago, Illinois, and University of California at Los Angeles School of Medicine, ${ }^{4}$ Los Angeles, California, USA

ABSTRACT Data on respiratory symptoms and pulmonary function were obtained for 2736 Portland cement plant workers and 755 controls. Personal dust samples contained a geometric mean concentration of $0.57 \mathrm{mg} / \mathrm{m}^{3}$ for respirable dust and $2.90 \mathrm{mg} / \mathrm{m}^{3}$ for total dust. Cement workers and controls had similar prevalences of symptoms, except that $5.4 \%$ of the cement workers had dyspnoea compared with $2.7 \%$ of the controls. The mean pulmonary function indices were similar for the two groups. Among cement plant workers, the prevalence of chronic phlegm increased with tenure whereas the prevalence of wheezing increased with both tenure and current dust level. Other symptoms and pulmonary function indices were not significantly related to exposure.

Previous evidence for associations between exposure to Portland cement dust and either respiratory symptoms or functional impairment has been inconclusive. Both non-smoking and smoking Yugoslavian cement workers had a higher prevalence of chronic bronchitis ${ }^{1}$ and airflow obstruction ${ }^{2}$ than controls. In Egyptian cement workers the ratio of the forced expiratory volume in one second $\left(\mathrm{FEV}_{1}\right)$ to the forced vital capacity (FVC) for 30-49 year old smokers in dusty jobs was significantly lower than for controls, although for smokers in other age groups and for non-smokers there were no differences. ${ }^{3}$ No differences in spirometric measurements were found by comparing Danish cement workers with other blue collar workers with similar smoking habits. ${ }^{4}$ Other studies of symptoms or ventilatory function have either lacked controls, failed to account for the effects of smoking, or both. ${ }^{5-9}$

Mention of brand names does not constitute endorsement by NIOSH.

Accepted 11 May 1987
We report here the results of a controlled cross sectional study of respiratory symptoms and ventilatory function in Portland cement plant workers conducted by the United States National Institute for Occupational Safety and Health (NIOSH) from 1979 to 1982. Radiographic findings will be the subject of a separate report.

\section{Methods}

STUDY POPULATION

From about 150 Portland cement manufacturing plants which employed between 100 and 500 people, 16 plants were randomly selected by stratifying on plant age-that is, the age of the oldest operating kiln-and the type of process (whether dry, wet, or both forms of raw materials were fed to the kiln). Table 1 shows the sample distribution. The number of workers per cell was approximately $10 \%$ of each cell's representation within the industry. All hourly and salaried workers were invited to take part except at one

Table 1 Distribution of cement workers examined by age of plant and type of process

\begin{tabular}{lcccr}
\hline & Before 1941 & $1941-60$ & $1961-78$ & All ages \\
\hline Wet & $250(9 \cdot 1 \%)$ & $545(19 \cdot 9 \%)$ & $325(11.9 \%)$ & $1120(40 \cdot 9 \%)$ \\
Dry & $202(7 \cdot 4 \%)$ & $604(22 \cdot 1 \%)$ & $570(20 \cdot 8 \%)$ & $1376(50 \cdot 3 \%)$ \\
Both & $0(0 \cdot 0 \%)$ & $242(8 \cdot 8 \%)$ & $0(0 \cdot 0 \%)$ & $242(8.8 \%)$ \\
Total & $452(16 \cdot 5 \%)$ & $1391(50 \cdot 8 \%)$ & $895(32 \cdot 7 \%)$ & $2738(100 \cdot 0 \%)$ \\
\hline
\end{tabular}


plant where, for convenience, only hourly production and maintenance workers were studied.

\section{CONTROLS}

Controls consisted of workers from 10 plants in various non-cement industries. About half worked in machine shop or assembly operations in machinery manufacturing plants whereas the rest were employed in bottling and distributing soft drinks, manufacturing electrical and electronic equipment, or in a dairy. Production workers from either entire plants or selected departments with at least 50 employees were invited for testing; office workers were excluded. We selected plants which had work environments that were relatively free from substantial respiratory hazards, although it was not our intention that the control group should work in a pristine environment. Since our primary aim was to study the effect of cement plant dust per se, we chose controls who had exposures to non-cement dust similar to those of the cement workers, about half of whom performed maintenance or laboratory jobs that exposed them to inhaled non-cement substances such as solvent vapours. Based on careful inspection of the control plants, we excluded individuals, such as full time welders, grinders, and spray painters, whose respiratory exposures were likely to have exceeded the cement plant background level. Selected measurements were then made of the concentrations of various contaminants, such as respirable and total dust, organic hydrocarbons, ammonia, nitrogen dioxide, and toxic metals. Further exclusions from the analysis were made for individuals whose exposure exceeded half of the 1982 threshold limit value of the Americal Conference of Governmental Industrial Hygienists. ${ }^{10}$ This resulted in the exclusion of nine additional individuals after testing was completed but without prior knowledge of their symptoms or spirometry results. Twelve additional individuals were excluded because of previous work in cement plants.

\section{TESTING PROTOCOL}

The protocol was approved by the Human Subjects Review Board of NIOSH. Informed voluntary consent was obtained from each subject. Standing height and weight were measured. A NIOSH modification" of the Medical Research Council questionnaire on respiratory symptoms ${ }^{12}$ was administered by trained interviewers, and data were also obtained on demographic characteristics, occupational history, and smoking habits. A translation of the questionnaire was used for Spanish speaking subjects who were not fluent in English. Subjects were classified as "non-smokers" if they had never smoked, "ex-smokers" if they had stopped smoking cigarettes before their previous birthday, "smokers" if they had smoked cigarettes
Table 2 Definitions of symptoms and syndromes

\begin{tabular}{|c|c|c|}
\hline Symptom or syndrome & \multicolumn{2}{|l|}{ Definition } \\
\hline Chronic cough & \multirow{2}{*}{\multicolumn{2}{|c|}{$\begin{array}{l}\text { Cough part of day or entire day for at least } 3 \\
\text { months each year } \\
\text { Phlegm part of day or entire day for at least } 3 \\
\text { months each year }\end{array}$}} \\
\hline Chronic phlegm & & \\
\hline $\begin{array}{l}\text { Chronic bronchitis } \\
\text { with exacerbations }\end{array}$ & \multirow{2}{*}{\multicolumn{2}{|c|}{$\begin{array}{l}\text { Chronic phlegm and at least } 1 \text { exacerbation } \\
\text { in past } 3 \text { years } \\
\text { Chronic phlegm entire day and: }\end{array}$}} \\
\hline Chronic bronchitis & & \\
\hline & $F E V_{1} / F V C$ & Age \\
\hline & $\begin{array}{l}\leqslant 0 \cdot 79 \\
\leqslant 0.76 \\
\leqslant 0 \cdot 74 \\
\leqslant 0.71\end{array}$ & $\begin{array}{l}25-9 \\
30-9 \\
40-9 \\
50-9\end{array}$ \\
\hline $\begin{array}{l}\text { Dyspnoea } \\
\text { Wheezing } \\
\text { Asthma }\end{array}$ & \multicolumn{2}{|c|}{$\begin{array}{l}\text { Dyspnoea walking on level ground } \\
\text { Wheezing on most days or nights } \\
\text { Attacks of dyspnoea with wheezing }\end{array}$} \\
\hline
\end{tabular}

*An episode of increased cough or phlegm lasting for at least three weeks.

since their last birthday, and "pipe/cigar" users if they currently or formerly had one of these habits and had never smoked cigarettes. Those who smoked pipes or cigars and also cigarettes were classified by the cigarette category. Analysis was performed on the following symptoms and syndromes: chronic cough, chronic phlegm, chronic bronchitis with exacerbations, chronic bronchitis with obstruction, dyspnoea, wheezing, and asthma (table 2).

Spirometry was performed during the workshift and consisted of at least five forced expirations into a waterless rolling sealed spirometer (Ohio Model 840) generating flow volume signals that were electronically recorded. At least three curves meeting American Thoracic Society standards ${ }^{13}$ were required from each subject for analysis. Measurements were converted to body temperature and pressure, saturated (BTPS). The FVC, FEV $_{1}$, and peak flow (PF) were taken at the maximum measurement of each parameter. Tracings were aligned at maximal inspiration and a composite curve constructed from the highest flow at each lung volume ${ }^{14}$ from which the forced expiratory flows after exhalation of $50 \%, 75 \%$ of the vital capacity $\left(\mathrm{FEF}_{50}\right.$ and $\mathrm{FEF}_{75}$ respectively) were taken.

\section{ESTIMATION OF EXPOSURE}

The cement making process generates dust from quarrying and preparing raw materials, from calcining and grinding clinker, and from blending, packing, and shipping the finished product. Other inhaled contaminants consist of additives (mainly gypsum), products of combustion of fuel (coal, oil, or natural gas), and exposures encountered in the maintenance of plant and equipment. Federal, state, and industry sources showed a lack of data from which previous 
environmental exposures could be estimated with reasonable accuracy.

Current exposures were estimated from sampling done within two weeks of the medical surveys, except in two plants where sampling was done 11 months earlier. Measurements were made of respirable dust, total airborne dust, respirable crystalline silica, asbestos, oxides of sulphur, and nitrogen dioxide. Standard analytical methods, described elsewhere, ${ }^{15}$ were used.

Jobs were classified according to the duties performed and the plant area with which they were associated. The plant areas, designated "raw," "clinker," "finished," and "mixed," reflected qualitative differences in the types of dust present. The raw area consisted of the quarry, primary crusher, raw mills, and raw material handling. The clinker area included the discharge end of the kiln and the clinker cooler. The finished area comprised the finished cement mills, blending, packing, storage, and loading. The mixed area included the yard, laboratory, offices, and plantwide maintenance and supervision. When the raw and finished mills were located together, they were considered to belong to the mixed area.

To determine the optimum strategy for sampling, a pilot environmental survey ${ }^{16}$ was conducted at five cement plants outside the 16 plant sample. Workers from various jobs, shifts, and plant areas were randomly selected and sampled for respirable and total dust on two consecutive days over a four day period. Analysis of components of variance showed that there was a large variation in respirable dust concentration from job to job and day to day but that intersubject variation alone was small. Thus dust exposure estimates could be based on either several measurements on one person or one measurement on each of several people.

Based on the results of the pilot study, four to six jobs per area were sampled in the full study. Within jobs, one to six individuals were selected for sampling on the basis of availability. Sampling was conducted for three days on the first shift and for one day on the second and third shifts. When more than one sample per job was obtained, the geometric mean was used to determine the dust level for job-within-plant. This was done for two reasons. Firstly, the geometric mean estimates the median of the distribution better than the

Table 3 Personal dust samples in the cement workers

\begin{tabular}{|c|c|c|c|c|}
\hline & No & $\begin{array}{l}\text { Mean } \\
\text { concentration* } \\
\left(\mathrm{mg} / \mathrm{m}^{3}\right)\end{array}$ & $\begin{array}{l}\text { Range } \\
\left(\mathbf{m g} / \mathrm{m}^{3}\right)\end{array}$ & $\begin{array}{l}\text { Samples greater } \\
\text { than } \\
\text { MSHA limit }\end{array}$ \\
\hline $\begin{array}{l}\text { Respirable } \\
\text { dust } \\
\text { Total dust }\end{array}$ & $\begin{array}{r}1011 \\
211\end{array}$ & $\begin{array}{l}0.57(3.60) \\
2.90(4.35)\end{array}$ & $\begin{array}{l}0.01-46.22 \\
0.01-78.61\end{array}$ & $\begin{array}{r}5 \% \\
19 \%\end{array}$ \\
\hline
\end{tabular}

*Geometric mean (SD).

†Mine Safety and Health Administration." levels, where dust is the dependent variable, the analysis should be performed using logarithms, and the geometric mean is the antilogarithm of the arithmetic mean of these logarithms. Individuals, whether sampled or not, were assigned, as their current exposure level, the geometric mean for their jobwithin-plant.

\section{DATA ANALYSIS}

For ventilatory function, linear models analysis was used, with adjustment for sex, race, age, height, smoking status, and pack-years of cigarettes. "Plant" was included in the model to adjust for possible interplant differences in outcome resulting from other confounding factors such as population differences or unmeasured exposures. Tests of significance were made with the $F$ test.

For symptoms, logistic analysis was used. This was similar to the linear models analysis; however, the dependent variable was $\ln (\mathrm{P} /(1-\mathrm{P}))$, where $P$ is a symptom prevalence. Adjustment was made for sex, age, smoking status, and pack-years of cigarettes. Plant was excluded from the model because, for certain symptoms, some plants had prevalences of zero, which would have prevented estimation and testing. Outcomes were expressed as adjusted odds ratios $\left(\mathrm{OR}_{\mathrm{adj}}\right)$ and tested for significance by the likelihood ratio chi-squared test.

Three types of comparisons were made. The first compared cement workers with controls. The second examined differences among the cement plant areas, using as the exposure variable the area in which each cement worker had served the majority of his cement plant tenure. If no single area accounted for a majority, the worker was placed in the "mixed" category. Because we were interested in the effects of chronic exposure, this analysis was done only for cement workers with at least eight years of tenure. For the third type of comparison, an exposure response surface for cement workers was fitted using current respirable or total dust level, job tenure, and the interaction - that is, the product - of dust level and tenure. Tenure was separated between current cement job and previous cement jobs because the current dust levels probably had less validity for jobs performed in the past. In all cases differences were considered significant when the $p$ values were less than or equal to 0.05 . Further details are given in the appendix.

\section{Results}

CURRENT ENVIRONMENTAL EXPOSURES

A total of 1011 personal respirable dust samples and 211 personal total dust samples was collected; the data are summarised in table 3 . Five per cent of the respirable dust samples and $19 \%$ of the total dust 
Table 4 Personal quartz samples in the cement workers

\begin{tabular}{|c|c|c|c|c|c|c|}
\hline \multirow[b]{2}{*}{$\begin{array}{l}\text { Plant } \\
\text { area }\end{array}$} & \multirow[b]{2}{*}{$\begin{array}{l}\text { No of } \\
\text { samples }\end{array}$} & \multirow[b]{2}{*}{$\begin{array}{l}\text { Mean } \\
\text { respirable } \\
\text { dust }^{*}\left(\mathrm{mg} / \mathrm{m}^{3}\right)\end{array}$} & \multirow[b]{2}{*}{$\begin{array}{l}\text { Samples with } \\
\text { detectable } \\
\text { quartz }\end{array}$} & \multirow[b]{2}{*}{$\begin{array}{l}\text { Median quartz } \dagger \\
\text { dust }\left(\mathrm{mg} / \mathrm{m}^{3}\right)\end{array}$} & \multicolumn{2}{|c|}{$\begin{array}{l}\text { Per cent of samples with quartz } \\
\text { exceeding }\end{array}$} \\
\hline & & & & & $\begin{array}{l}\text { MSHA } \\
\text { limit }^{17}\end{array}$ & $\begin{array}{l}\text { NIOSH } \\
\text { standard }^{18}\end{array}$ \\
\hline $\begin{array}{l}\text { Raw } \\
\text { Clinker } \\
\text { Finished } \\
\text { Mixed } \\
\text { All }\end{array}$ & $\begin{array}{r}215 \\
133 \\
177 \\
482 \\
1007\end{array}$ & $\begin{array}{l}0.48 \\
0.48 \\
0.85 \\
0.55 \\
0.57\end{array}$ & $\begin{array}{r}60(27 \cdot 9 \%) \\
11(8 \cdot 3 \%) \\
5(2 \cdot 8 \%) \\
69(14 \cdot 3 \%) \\
145(14 \cdot 4 \%)\end{array}$ & $\begin{array}{l}0.085 \\
0.072 \\
0.056 \\
0.081 \\
0.079\end{array}$ & $\begin{array}{r}16.4 \% \\
4.5 \% \\
1.7 \% \\
7.7 \% \\
8.1 \%\end{array}$ & $\begin{array}{r}21 \cdot 4 \% \\
5.3 \% \\
1 \cdot 7 \% \\
10 \cdot 8 \% \\
10 \cdot 8 \%\end{array}$ \\
\hline
\end{tabular}

*Geometric mean.

†For samples with detectable quartz.

samples exceeded the existing and recommended United States exposure limits. ${ }^{17}$ Dust concentrations were distributed with positive skewness for all samples and within each job and plant. Analysis of variance, using the logarithms of the dust concentrations, showed that individual measurements varied significantly by job $(p \leqslant 0.01)$, shift $(p \leqslant 0 \cdot 01)$, and plant $(p \leqslant 0.01)$ for respirable dust, and by job alone $(p \leqslant$ $0 \cdot 05$ ) for total dust. Plant age, type of process, and the interaction of age and type of process did not influence the concentration of either type of dust. ${ }^{15}$

Quartz was detected in $14.4 \%$ of the personal respirable dust samples which were analysed for crystalline silica. The median concentration in samples having detectable quartz was $0.079 \mathrm{mg} / \mathrm{m}^{3}$ (table 4). Respirable quartz was found most often and in the highest concentrations in samples from the raw area, followed by the mixed, clinker, and finished areas. Analysis of bulk materials for quartz gave the same ranking of plant areas. The proportion of samples with detectable quartz varied significantly from plant to plant, probably due to differences in raw materials. No cristobalite was found in the personal or the bulk samples.

In 195 area samples of airborne dust and 292 bulk material samples no asbestos or other mineral fibres were found. Compared with existing and recommended exposure limits, ${ }^{192}$ levels of $\mathrm{SO}_{2}$ and $\mathrm{NO}_{2}$ were low.

\section{POPULATION CHARACTERISTICS}

Altogether 2738 cement workers $(86.9 \%$ of those invited) and 776 controls (73.7\%) took part in the study. Two cement workers were excluded from analysis because of missing questionnaire data. Twenty one controls were excluded because of substantial exposure to respiratory hazards or previous work in cement plants. The cohort for analysis consisted of 2736 cement workers and 755 controls. Table 5 shows the demographic characteristics and smoking habits of the cohort.

The interplant variations of the prevalence of chronic bronchitis and of $\mathrm{FEV}_{1}$ among the control plants were tested with the logistic and linear models after adjusting for confounding variables. There was no significant interplant variation, indicating that with respect to these characteristics the control plants could be regarded as samples from the same population.

CEMENT WORKERS $v$ CONTROLS

Table 6 shows the crude prevalences and adjusted odds

Table 5 Demographic and smoking data

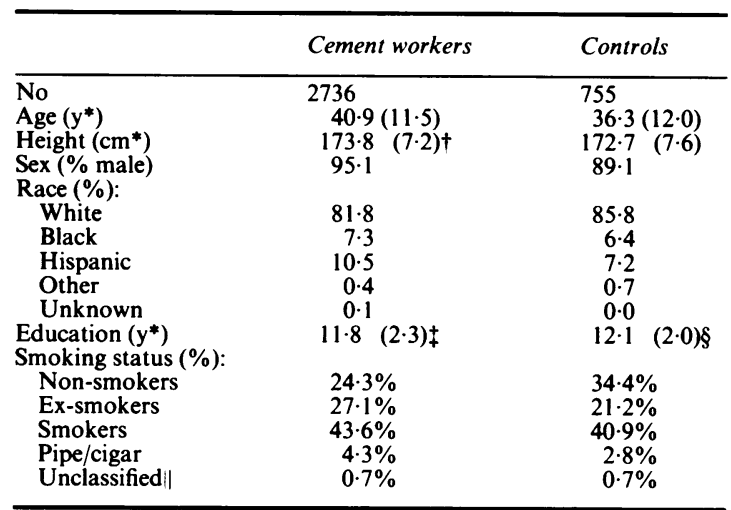

*Mean (SD). $\lceil n=2733 . \ddagger n=2728 . \S=753 . \|$ deleted from analysis.

Table 6 Respiratory symptoms and syndromes

\begin{tabular}{|c|c|c|c|c|}
\hline & \multicolumn{2}{|c|}{ Crude prevalence } & \multirow{2}{*}{$\begin{array}{l}\text { Adjusted } \\
\text { odds } \\
\text { ratio* }\end{array}$} & \multirow[b]{2}{*}{$p^{\dagger}$} \\
\hline & $\begin{array}{l}\text { Cement } \\
\text { workers }\end{array}$ & Controls & & \\
\hline Chronic cough & $15 \cdot 4 \%$ & $13 \cdot 8 \%$ & 0.96 & 0.73 \\
\hline Chronic phlegm & $18 \cdot 2 \%$ & $16 \cdot 1 \%$ & 1.06 & 0.65 \\
\hline $\begin{array}{l}\text { Chronic bronchitis } \\
\text { with exacerbations } \\
\text { Conchitis }\end{array}$ & $5 \cdot 8 \%$ & $4 \cdot 1 \%$ & 1.41 & 0.08 \\
\hline $\begin{array}{l}\text { Chronic bronchitis } \\
\text { with obstruction }\end{array}$ & $4 \cdot 1 \%$ & $3.0 \%$ & $1 \cdot 18$ & 0.54 \\
\hline Dyspnoea & $5 \cdot 4 \%$ & $2.7 \%$ & $1 \cdot 60$ & 0.05 \\
\hline Wheezing & $8 \cdot 5 \%$ & $7 \cdot 7 \%$ & 0.93 & 0.63 \\
\hline Asthma & $8 \cdot 7 \%$ & $8.9 \%$ & $0 \cdot 88$ & 0.40 \\
\hline
\end{tabular}

*Odds ratios adjusted for age, sex, and smoking. Subjects with unclassified smoking deleted.

tp Value for testing the hypothesis that $\mathrm{OR}_{\mathrm{adj}}=1$, using the likelihood ratio chi-squared test. 
Table 7 Ventilatory function

\begin{tabular}{|c|c|c|c|c|c|}
\hline & \multicolumn{2}{|l|}{ Crude means } & \multicolumn{3}{|l|}{ Adjusted means* } \\
\hline & Cement workers & Controls & Cement workers & Controls & $p \dagger$ \\
\hline $\begin{array}{l}\text { No } \\
\text { FVC (1) } \neq \\
\text { FEV }(1) \\
\text { PF (l/s) } \\
\text { FEF }(1 / s) \\
\text { FEF }_{75}(1 / s)\end{array}$ & $\begin{array}{l}2607 \\
4.87(0.88) \\
3.76(0.80) \\
9.47(2.01) \\
4.59(1.65) \\
1.49(0.77)\end{array}$ & $\begin{array}{l}729 \\
4.88(0.89) \\
3.85(0.78) \\
9.52(1.93) \\
4.76(1.55) \\
1.68(0.82)\end{array}$ & $\begin{array}{l}4.47 \\
3.51 \\
8.87 \\
4.60 \\
1.49\end{array}$ & $\begin{array}{l}4.45 \\
3.51 \\
8.85 \\
4.57 \\
1.51\end{array}$ & $\begin{array}{l}0.76 \\
0.93 \\
0.94 \\
0.77 \\
0.74\end{array}$ \\
\hline
\end{tabular}

*Adjusted for age, sex, race, height, and smoking, with plant nested within group.

$t p$ Value for testing the hypothesis that the cement workers and controls have the same adjusted means, using the $F$ test. †Mean (SD).

ratios of symptoms and syndromes in cement workers and controls. The cement workers had a significantly raised adjusted odds ratio for dyspnoea $(p \leqslant 0.05)$. This was unaltered by adding the interaction of smoking status and group, indicating an equivalent effect in all smoking categories. No significant differences were found in the prevalences of the other symptoms and syndromes.

Table 7 gives the crude and adjusted means for ventilatory function. For none of the variables did the means significantly differ between cement workers and controls after adjustment for confounding factors.

EFFECT OF PLANT AREA

There were no relations between plant area and the prevalence of symptoms. For workers who had spent most of their tenure in the mixed area, the adjusted mean FVC was larger, 4.351 , compared with 4.241 for raw, 4.231 for finished, and 4.171 for clinker (p $\leqslant$ 0.01 ). The interaction of plant area and smoking status was not significant, indicating that the effect was equivalent in all smoking categories. There was no relation between plant area and any of the other ventilatory function variables.

\section{EXPOSURE RESPONSE RELATIONS}

In the 2298 cement workers with respirable dust values the prevalence of chronic phlegm was positively related to tenure $(p \leqslant 0.05)$. The adjusted odds ratio relative to zero exposure was:

$$
\mathrm{OR}_{\mathrm{adj}}=\mathrm{e}^{0.0020(\mathrm{PJT})}
$$

The relation was also significant among the 1040 subjects with total dust measurements but the estimated coefficients were less precise because the sample size was smaller. The prevalence of wheezing was positively related to current respirable dust concentration and tenure $(p \leqslant 0 \cdot 05)$. The adjusted odds ratio was:

$$
O R_{\text {adj }}=\mathrm{e}^{0.1205(\mathrm{RD})+0.0020(\mathrm{PJT})} \text {. }
$$

For neither chronic phlegm nor wheezing were the interactions of the significant exposure terms and smoking status significant, indicating that the odds
Table 8 Significant exposure response relations in the

\begin{tabular}{|c|c|c|c|c|c|}
\hline & \multicolumn{5}{|c|}{ Previous job tenure (y) } \\
\hline & 0 & 5 & 10 & 20 & 30 \\
\hline $\begin{array}{l}\text { Chronic phlegm:* } \\
\text { OR }{ }_{\text {adj: }}: \\
\text { Wheezing:* } \\
\text { Current respirable dust } \\
\left(\mathrm{mg} / \mathrm{m}^{3}\right)\end{array}$ & 1.00 & $1 \cdot 12$ & $1 \cdot 26$ & 1.60 & $2 \cdot 02$ \\
\hline $\begin{array}{l}0 \\
1 \\
3 \\
5\end{array}$ & $\begin{array}{l}1.00 \\
1.13 \\
1.44 \\
1.83\end{array}$ & $\begin{array}{l}1.13 \\
1.27 \\
1.62 \\
2 \cdot 06\end{array}$ & $\begin{array}{l}1 \cdot 27 \\
1 \cdot 44 \\
1 \cdot 83 \\
2 \cdot 33\end{array}$ & $\begin{array}{l}1 \cdot 62 \\
1 \cdot 83 \\
2 \cdot 33 \\
2 \cdot 96\end{array}$ & $\begin{array}{l}2 \cdot 06 \\
2 \cdot 33 \\
2 \cdot 96 \\
3 \cdot 77\end{array}$ \\
\hline
\end{tabular}
cement workers

${ }^{*} p \leqslant 0 \cdot 05$. The equations are given in the text.

ratios were equivalent for all smoking categories. Values of the odds ratios for various periods of tenure and, for wheezing, current concentrations of dust, are shown in table 8. The other symptoms were not significantly related to exposure.

The only measurement of ventilatory function that correlated with exposure was peak flow, which was negatively related to current respirable dust concentration (regression coefficient $=-103.2 \mathrm{ml} / \mathrm{sec} /$ $\left.\mathrm{mg} / \mathrm{m}^{3}, \mathrm{p} \leqslant 0.01\right)$. Neither tenure nor the interaction of dust concentration and tenure was significant. Thus there was no evidence that individuals with longer exposure were more severely affected. The interaction of respirable dust concentration and smoking status was not significant, indicating an equivalent effect in all smoking categories.

\section{Discussion}

This is the first controlled epidemiological study of the respiratory effects of Portland cement plant dust performed in the United States. We observed no significant differences in symptoms between cement workers and controls, except that a higher proportion of cement workers claimed to have dyspnoea. This was not explained by a reported history of heart trouble. Because there were no differences in ventilatory function, the higher prevalence of dyspnoea may reflect 
Table 9 Comparison of white men with Yugoslavian cement workers

\begin{tabular}{|c|c|c|}
\hline & $\begin{array}{l}\text { Present } \\
\text { study }\end{array}$ & $\begin{array}{l}\text { Yugoslavian } \\
\text { cement } \\
\text { workers }\end{array}$ \\
\hline No & 1724 & 847 \\
\hline \multicolumn{3}{|l|}{ Crude prevalence of symptoms $(\%)$ : } \\
\hline Chronic cough & $\begin{array}{l}17 \cdot 4 \\
10.7\end{array}$ & $41 \cdot 6$ \\
\hline Chronic phlegm & $19 \cdot 7$ & $37 \cdot 8$ \\
\hline $\begin{array}{l}\text { Chronic bronchitis with exacerba- } \\
\text { tions }\end{array}$ & $3 \cdot 7$ & 1.6 \\
\hline Chronic bronchitis with obstruction & 4.9 & $11 \cdot 2$ \\
\hline Dyspnoea & $5 \cdot 5$ & $8 \cdot 5$ \\
\hline Wheeze & $\mathbf{9 \cdot 3}$ & $7 \cdot 4$ \\
\hline Asthma & 8.8 & $3 \cdot 0$ \\
\hline Age $(y) \dagger$ & $41 \cdot 1(9 \cdot 9)$ & $39.9(6 \cdot 8)$ \\
\hline \multicolumn{3}{|l|}{ Smoking status (\%): $\ddagger$} \\
\hline Non-smokers & $21 \cdot 8$ & $23 \cdot 3$ \\
\hline Ex-smokers & $30 \cdot 7$ & $18 \cdot 3$ \\
\hline Light smokers & $7 \cdot 0$ & $10 \cdot 5$ \\
\hline Moderate smokers & $20 \cdot 4$ & $34 \cdot 2$ \\
\hline Heavy smokers & $20 \cdot 0$ & $13 \cdot 7$ \\
\hline
\end{tabular}

*For this comparison, the present study definition was changed to require phlegm production for the entire day.

tMean (SD).

$\ddagger$ Definitions conform to reference 1 .

merely a greater propensity of exposed individuals to perceive and report symptoms.

Our results with respect to ventilatory function agree with those of Rasmussen et al, ${ }^{4}$ who found no differences in the spirometric measurements of Danish cement workers and other blue collar workers with similar smoking habits. With respect to both ventilatory function and symptoms, however, our results differ from those of Kalacic, ${ }^{2}$ who found a higher prevalence of chronic bronchitis and airflow obstruction in both smoking and non-smoking Yugoslavian cement workers than in corresponding controls. Kalacic's data are compared with ours in table 9. Using our smoking specific rates as the standard, the indirectly adjusted Yugoslavian expected prevalence of chronic bronchitis with obstruction was $4.6 \%$, which is significantly lower $(p \leqslant 0.01)$ than the $11.2 \%$ observed in Kalacic's study. Therefore, the higher Yugoslavian prevalence was unlikely to have been due to differences in smoking, and probably reflected their considerably higher dust exposure (M Saric, unpublished observations).

The inclusion of "plant" in the model for data analysis should not have obscured or removed effects due to the exposure variables in the model such as job tenure or current dust concentration. It is possible, however, that the plant effect, which was always significant in the spirometry analysis, could in fact have been related to some other exposure. Because the data were collected by cluster sampling, the plant effect was confounded with time, and thus its significance could have had several possible origins. We were unable to find any clear patterns, however, with respect to the order of data collection, pulmonary function technicians, or known exposures.

It is unlikely that our negative findings were due to the masking of true effects of exposure to dust. Firstly, the effect of dust was probably not obscured by low tenure, because the median tenure of the cement workers was 10.9 years (range: 0 to 45.3 ). Secondly, the control group was selected with care so that the prevalence, nature and intensity of exposure to inhaled substances closely resembled the background exposure of the cement workers to non-cement inhaled substances. Had we not chosen controls with such background exposures, we could not have conducted a valid test of the respiratory effects of cement dust per se, because any observed differences could have been attributed to the cement workers' exposure to noncement inhaled substances as well as to cement dust. That we were consistently able to select controls with similar low levels of exposure to non-cement inhaled substances is supported by the lack of significant differences in adjusted chronic phlegm prevalence and FEV, among control plants. Thirdly, there is little likelihood that we failed to detect true differences in key variables due to type II errors. For FEV estimated power to detect a true difference between the groups of 0.11 was 0.90 . For chronic phlegm, the estimated powers were 0.65 and 1.00 for true odds ratios of 1.3 and 1.6 respectively. For chronic bronchitis with obstruction, the estimated power was 1.00 for a true odds ratio of $2 \cdot 67$, representing the relative risk corresponding to a 0.05 rise in prevalence among cement plant workers over controls. Finally, we think that the validity of our findings is strengthened by the high rate of participation by the cement workers and by the adjustment for confounding variables.

As a cross sectional study, however, our data are subject to inherent potential bias due to the possible prior withdrawal of susceptible individuals from the exposed population (the "survivor effect"). The influence of this potential bias cannot be estimated without either a longitudinal study or the examination of former workers.

Considering the lack of differences between the cement workers and the controls, we think that the implications of exposure response associations are of minor importance. The association, however, of chronic phlegm with previous job tenure suggests a possible relation between exposure to cement plant dust and industrial bronchitis. ${ }^{21}$ The exposure related reduction in peak flow represents about a $1-2 \%$ drop per $\mathrm{mg} / \mathrm{m}^{3}$ of respirable dust. Because peak flow was not related to tenure, the reduction was probably a transient acute effect. Nevertheless, Saric (unpublished observations) observed only a negligible change in FEV $_{1}$ over a workshift in Yugoslavian cement workers exposed to levels between $3 \cdot 3$ and $30 \mathrm{mg} / \mathrm{m}^{3}$ of 
respirable dust, and no significant change in airways resistance after similar concentrations administered in an exposure chamber.

Our sample of 16 cement plants was representative of the United States industry with respect to plant age, process type, and geographical distribution. We found that dust concentrations were a function of plant, job, and shift but were not influenced by plant age or type of process. Five per cent of samples exceeded the current exposure limit for respirable dust, $19 \%$ exceeded the limit for total dust, and $8.1 \%$ exceeded the limit for respirable silica ${ }^{17}$ (tables 3 and 4). We found no asbestos in the bulk materials or the airborne dust.

We conclude that a close relation between exposure to cement plant dust at levels existing in the United States and respiratory symptoms or ventilatory function is lacking. It would be worth while, however, performing further well controlled studies in other countries where exposures may be higher.

\section{Appendix}

For ventilatory function, the general model was:

$$
\begin{aligned}
& \mathrm{y}=\mathrm{b}_{0}+\mathrm{sex}+\text { race }+\mathrm{b}_{1}(\mathrm{age})+\mathrm{b}_{2} \text { (height) }+ \\
& \text { smoking status }+ \text { pack-years*smoking status }+ \\
& \text { age*smoking status + plant + exposure, }
\end{aligned}
$$

where $y$ is a ventilatory function index, and ${ }^{*}$ denotes an interaction term. For comparisons with controls, plant was nested within group and its mean square formed the denominator of the $F$ test for group differences. For analyses involving only cement workers, plant was simply treated as a confounder.

For symptoms, the general model was:

$\ln [\mathrm{P} /(1-\mathrm{P})]=\mathrm{b}_{0}+\operatorname{sex}+\mathrm{b}_{1}($ age $)+$ smoking status + pack-years*smoking status + age*smoking status

$$
+ \text { exposure, }
$$

where $\mathbf{P}$ is a symptom prevalence.

For comparisons with controls or among cement plant areas, "exposure" was replaced in the models by group or area respectively. In the exposure response analysis the term for exposure in each model was replaced by:

$$
\begin{gathered}
b_{3} D+b_{4}(C J T)+b_{5}(\text { PJT })+b_{6}\left(D^{*} C J T\right)+ \\
b_{7}\left(D^{*} \text { PJT }\right),
\end{gathered}
$$

where $\mathrm{D}=$ current respirable dust (RD) or total dust (TD) concentration $\left(\mathrm{mg} / \mathrm{m}^{3}\right), \mathrm{CJT}=$ current job tenure (months), $\mathrm{PJT}=$ previous cement job tenure (months), and $\mathrm{D}^{*} \mathrm{CJT}$ and $\mathrm{D}^{*} \mathrm{PJT}$ are the interactions of current dust concentration with current and previous job tenure respectively. Tests were made by comparing models with and without the exposure terms. The first step was to test the five terms in combination. If this was not significant further testing was not performed. If significant the interactions and then the main exposure terms were tested in various combinations and non-significant terms were eliminated. The final model contained only significant terms and those required to make the model hierarchical.

An estimate of statistical power was made for the comparisons of cement workers and controls with respect to $\mathrm{FEV}_{1}$, chronic phlegm, and chronic bronchitis with obstruction. This was done by subtracting the estimated group difference, which was found when the analysis was performed, from each cement worker's predicted value (based on the fitted model), and then adding the difference of interest to this result. Random normal numbers with the appropriate variance were generated using the Statistical Analysis System function RANNOR ${ }^{22}$ and added to the above sum, and the result was used as the dependent variable. The test was then run 20 times, and the power estimate was the proportion of runs for which the test was statistically significant. This procedure takes into account any interrelations among the independent variables.

We are grateful for the help of Steven W Lenhart, who was originally in charge of the environmental assessment and Hope Lafferty, who helped with training interviewers and gathering field data.

\section{References}

1 Kalacic I. Chronic nonspecific lung disease in cement workers. Arch Environ Health 1973;26:78-83.

2 Kalacic I. Ventilatory lung function in cement workers. Arch Environ Health 1973;26:84-5.

3 El-Sewefy AZ, Awad S, Metwally M. Spirometric measurements in an Egyptian Portland cement factory. Journal of the Egyptian Medical Association 1970;53:179-86.

4 Rasmussen FV, Borchsenius L, Holstein B, Solvsteen P. Lung function and long-term exposure to cement dust. Scand $J$ Respir Dis 1977;58:252-64.

5 Maestrelli P, Simonato L, Bartolucci GB, Gemignani C, Maffessanti MM. Distribution of pneumoconiosis and chronic bronchitis in cement workers. Med Lav 1979;70:195-202.

6 Jenny VM, Battig K, Horisberger B, Havas L, Grandjean E. Industrial medicine investigation in cement factories. Schweiz Med Wochenschr 1960;26:705-9.

7 Vyskocil J. Long-term follow-up of chronic bronchitis in hydraulic cement workers. Vnitr Lek 1968;14:341-8.

8 Giuliani V, Belli R. Occupational hazards for cement workers. Med Lav 1955;46:715-24.

9 Popovic D. Contribution to the diagnosis of pneumoconiosis of workers in the cement industry. Arh Hig Rada Toksikol 1964;15:353-76.

10 American Conference of Governmental Industrial Hygienists. Threshold limit values for chemical substances and physical agents. Cincinnati: ACGIH, 1982.

11 Petersen M, Castellan RM. Prevalence of chest symptoms in nonexposed blue-collar workers. J Occup Med 1984;26:367-74.

12 Medical Research Council. Committee report on the aetiology of chronic bronchitis: definition and classification of chronic bronchitis for clinical and epidemiological purposes. Lancet 1965;i:775-9. 
13 American Thoracic Society. ATS statement-Snowbird workshop on standardization of spirometry. Am Rev Respir Dis 1979;119:831-8.

14 Knudson RJ, Slatin RC, Lebowitz MD, Burrows B. The maximum expiratory flow-volume curve: normal standards, variability, and effects of age. Am Rev Respir Dis 1976;113: $587-600$.

15 Abrons HL, Sanderson WT, Petersen MR. Respiratory effects of Portland cement dust. Morgantown, WV: National Institute for Occupational Safety and Health, 1985.

16 Petersen MR, Sanderson WT, Lenhart SW. Application of a pilot study to the development of an industrial hygiene sampling strategy. Am Ind Hyg Assoc J 1986;47:655-8.

17 Mining Enforcement and Safety Administration. Health and safety standards-sand, gravel, and crushed stone operations. Federal Register (July 1) 1974;39:24318.
18 National Institute for Occupational Safety and Health. Criteria for a recommended standard for occupational exposure to crystalline silica. Washington: Department of Health, Education, and Welfare, 1974. (DHEW (NIOSH) No 75-120.)

19 National Institute for Occupational Safety and Health. Criteria for a recommended standard for occupational exposure to sulfur dioxide. Washington: Department of Health, Education, and Welfare, 1974. (DHEW (NIOSH) No 74-111.)

20 National Institute for Occupational Safety and Health. Criteria for a recommended standard to nitrogen dioxide. Washington: Department of Health, Education, and Welfare, 1976. (DHEW (NIOSH) No 76-149.)

21 Morgan WKC. Industrial bronchitis. Br J Ind Med 1978;35: 285-91.

22 SAS Institute Inc. SAS user's guide: basics. Cary, NC: SAS Institute Inc, 1982.

\section{Vancouver style}

All manuscripts submitted to the $B r J$ Ind Med should conform to the uniform requirements for manuscripts submitted to biomedical journals (known as the Vancouver style)

The Br J Ind Med, together with many other international biomedical journals, has agreed to accept articles prepared in accordance with the Vancouver style. The style (described in full in $\mathrm{Br}$ Med J, 24 February 1979, p 532) is intended to standardise requirements for authors.

References should be numbered consecutively in the order in which they are first mentioned in the text by Arabic numerals above the line on each occasion the reference is cited (Manson ${ }^{1}$ confirmed other reports ${ }^{2-5} \ldots$ ). In future references to papers submitted to the $\mathrm{Br} J$ Ind Med should include: the names of all authors if there are six or less or, if there are more, the first three followed by et al; the title of journal articles or book chapters; the titles of journals abbreviated according to the style of Index Medicus; and the first and final page numbers of the article or chapter.

Examples of common forms of references are:

I International Steering Committee of Medical Editors. Uniform requirements for manuscripts submitted to biomedical journals. Br Med J 1979;1:532-5.

2 Soter NA, Wasserman SI, Austen KF. Cold urticaria: release into the circulation of histamine and eosino-phil chemotactic factor of anaphylaxis during cold challenge. $N \mathrm{Engl}$ $J$ Med 1976;294:687-90.

3 Weinstein L, Swartz MN. Pathogenic properties of invading micro-organisms. In: Sodeman WA Jr, Sodeman WA, eds. Pathologic physiology: mechanisms of disease. Philadelphia: W B Saunders, 1974:457-72. 